\title{
A mother's hope in the midst of existential immobility from state and stigma
}

\author{
Katherine Smith
}

\begin{abstract}
The article is situated ethnographically in households on the main social housing estate in Harpurhey, North Manchester, England. It explores the affective dynamics of motherhood and imaginations of the future with a backdrop of prolonged government disinvestment. We follow the experiences of a mother and her son as they deal with moments of uncertainty and attempt to imagine and prepare for his future free from dependence on state welfare. Considering that parenting marks time in the most intimate of ways and it confronts parents with the passing of time in terms of biological "growth" that sequences time for us, this article addresses how and at what points dependence on the state, over time, reconfigures the affective dynamics of motherhood and imaginations of familial dependencies into the future.
\end{abstract}

Keywords: future-making, immobility, (inter)dependence, motherhood, parenting, poverty, UK, welfare

When Julie moved into her state-owned council property in Harpurhey, North Manchester, England, 25 years ago, she never expected to become a mother. Julie is 41 years old and has suffered with multiple medical pathologies throughout her life, which suggested she would not be able to have children. She remains fully reliant on welfare income, including Disability Living Allowance (DLA), Housing Benefit, and Child Allowance, which have formed the bulk of her weekly income until the present day. She is entirely dependent on state welfare to live and make ends meet. She has not had any form of employment since 1996. When she discovered that the abdominal discomfort she was feeling was in fact a pregnancy and that soon she would have a son born in 1998, she was ecstatic and, as she explains, about to become the one thing she had always wanted to be: a mother.

She and her son, Ben still live in the twobedroom, red brick council house in the center of a cul-de-sac on the edge of the main social housing estate in Harpurhey. Ben is 21 years old now and has few remaining friends who have not slipped into a life of crime, drug abuse and selling, or violence. None of Ben's friends have completed their GCSE's, A-Levels, ${ }^{1}$ and gone on to start a university degree like Ben. Ben is studying physical education at the University of Salford. He is currently about to begin his final 
year. He is thinking about a career as a physical education teacher in a secondary school in the United Kingdom, and he tentatively explains, "I think I might be good at it."

At the end of 2017, Julie and Ben were beginning to face two potential changes in circumstances, changes that threatened the future of their household finances and raised new anxieties about the future for them both. On the one hand, Julie was facing the rolling out of the most recent welfare reform, throughout the months of January and February 2018. Her DLA was to be transferred to what are now Personal Independence Payments (PIPs). In order for the transferal to occur, Julie was required to attend a new health assessment to determine whether or not she "qualified" for the new PIPs. Qualification for PIPs is determined by the capability and functioning of bodies themselves, regardless of the particular illnesses one suffers. As Julie explained to me, "You could have cancer and be dying, but if you can walk to the bus stop, you are considered fit to work." Julie's physical symptoms come and go and are often unpredictable. She was aware that the assessment does not take into account the paroxysmal capabilities of bodies. Nor does it take into account the persistence of unpredictability when it comes to determining the physical functions of suffering bodies.

On the other hand, Ben is approaching the end of his university degree and a potential moment of separation from the household. Leaving Harpurhey is an important potential milestone for Ben. Julie struggles to imagine a future in which Ben is free of the forms of state scrutiny and threats of loss that she deals with regularly and have become so familiar. The local networks of support available to them are proving insufficient as they struggle to figure out what it takes to leave Harpurhey and achieve a version of this "good life." For Julie, what a future beyond welfare dependence and repeated submission to the requirements of the state might look like has become unimaginable.

Both impending events demonstrate an intricate interdependence between Julie's dependence on state support to raise Ben into adulthood and
Ben's potential for independence from state welfare, from the household, and from Julie. As both moments approach, reconfigurations of familial dependencies and the gendered aspects of being a mother are placed in sharp relief. This article explores these reconfigurations and the intimate experiences of existential immobility as a mother, a caregiver, and a future-maker for one's child. It addresses what is at stake when a future beyond welfare dependence becomes unimaginable, at times inarticulable, and shows that the affective dynamics of motherhood introduce a persistence of hope in the face of unimaginable futures. It demonstrates that in Harpurhey, the management of uncertainty requires a commitment to the reproduction of the present, and is mediated by the collective awareness of the repetition involved in struggling to make ends meet.

Building on previous efforts to explore the "presentness" of uncertainty in everyday lives (e.g., Bryant 2016; Day et al. 1999), this article places Julie as a mother at the center of analysis (cf. Pina-Cabral 2018). It addresses the persistent and familiar prevention of the realization of a "good life" (Jansen 2015: 169), the very prevention of which is acknowledged and mapped onto imaginations of futures in Harpurhey. Simultaneously taking into account the intimacies of motherhood and the temporal conditions of parenthood alongside what it takes to budget and get by in the present, this article demonstrates ethnographically that the existential properties of the present are interrupted, ruptured, when we address the mother/ child relation, which introduces quite a different set of imaginations of the (generational) futures. Parenting punctuates and marks time for us and imposes linear recall of the past to be certain of a future despite not knowing, in the present, what that future will look like. The punctuated time of parenthood appears to interrupt the persistent present and familiarity of dependence on the state, by (re)introducing the significance of a mother's hope. This article explores how dependence on state welfare, as a mother who hopes for a better future for her son, involves the co- 
existence of a persistent present brought on by the requirements of the state and the multiple existential ruptures of her imagination and future work in the midst of the tensions between dependence and hope.

\section{Familiarity and imagination}

Harpurhey is a suburban area in Manchester, located just three and a half miles northeast of the city center. It is home to a large open-air market, a few locally run shops, a large grocery store, several empty, derelict buildings, a (now closed) police station, a well-established and well-attended food bank, and a small collection of pubs and social clubs scattered around the area, all within walking distance. Harpurhey also includes a large social housing estate with visible poverty in localized areas. The area suffers from extremely high crime, morbidity, and violence rates and has recently been flagged as the "most deprived area in Greater Manchester" by Manchester City Council. ${ }^{2}$

Over six years of ethnographic research with families and in households in and around the cul-de-sac, every household manages and depends on some form of state welfare. Every person who is collecting state welfare has experienced the sanctioning of their welfare income for various reasons and has had to be persistent and compliant with the local Job Centre and Work Clubs to regain or maintain their welfare income (Smith 2017a). Their livelihoods, lifestyles, and life chances have been affected significantly by the rolling out of welfare reforms by the previous coalition and recurring Conservative governments as well as the increased fear of more sanctions and cuts to welfare provisions.

It is little wonder why so many of my interlocutors spend so much time and effort mapping themselves onto the intersectional categories and stereotypes that inform policy and public and political discourse about the dependent "welfare recipient" in Britain today, rather than risk resisting or protesting these categories. They bend to the demands of the disciplinary devices used to incentivize and motivate welfare recipients (Cruikshank 1997; Koch 2015), and they perform the dominant image of what poverty should look like in order to make themselves relevant for certain welfare benefits to make ends meet (see Smith 2017a). Yet, they do not necessarily "progress" into independence from state support.

The families in the cul-de-sac share a familiar history that is punctuated with (sometimes expected, sometimes unexpected) moments of anxiety around how to make ends meet for themselves and their families. Financial uncertainty and dealing with the imposition of the state in the lives and pockets of welfare recipients has fostered a series of interdependent relations between neighbors and families and put new kinds of strains on existing relations of support. Similar to the maintenance of social and intimate relationships among friends and kin that Carol Stack described among the families living in The Flats in Jackson Harbor, Illinois, in the culde-sac in Harpurhey their urgent needs are met with a steady source of support from neighbors and family, which they all rely upon for survival (cf. 1974: 70). Neighbors and family come to "fill in the gaps" left by the state in its withdrawal of support (Smith 2017a).

At the end of 2017, five people in the cul-desac, including Julie, were facing the new assessment as part of the transferal of their DLA to PIPs. Within the months of January and February, 2018, each of them would have a date to attend. DLA was a means-tested welfare benefit in the United Kingdom, which was intended to help with the extra costs of living with a longterm health condition or disability. PIPs have the same purpose but are not means-tested. In the transfer from DLA to PIPs, all disability benefits (DLA) claimants must be assessed on the function of their bodies by a government-selected assessor. ${ }^{3}$ The medical assessment for PIPs is stricter than those were for DLA. For instance, when applying for DLA, a person could claim that they were "virtually unable to walk" and could not walk for more than 50 meters and were therefore eligible for DLA. Under PIPs, if 
you can walk for up to 20 meters (irrespective of diagnosed illnesses), you do not qualify for PIPs and lose your DLA as this form of benefits is becoming redundant. According to recent government welfare estimates, this assessment has already excluded over 420,000 people from accessing PIPs. ${ }^{4}$ At the time of writing, PIPs have not yet been fully "rolled out" across England alone; they are not finished yet. ${ }^{5}$

It is not surprising, then, to hear how many people who receive DLA benefit in Harpurhey are preparing for their PIPs assessment. Preparation involved learning from others around the cul-de-sac who had already had their assessment or discussed with others beyond the cul-de-sac their experiences of the assessment and brought the knowledge back home to share. In everyday conversation, they share experiences, information, tips, and advice about the assessment. They practice with each other and rehearse how they intend to respond to questions in their assessment. It is a productive moment. Neighbors are sharing experiences of the assessment, exchanging information as currency in the everyday reciprocal relations and exchanges in the culde-sac. The anxieties about the new assessment are dealt with in and through the endurance that can be found in already existing social relations.

For Julie, the build up to her PIPs assessment was a particular moment of anxiety as it was coupled with unexpected pressure from the Department for Work and Pensions to detail for them Ben's future movements after university. Prior to Julie's assessment, she spoke of her anxieties to me:

I find it [PIPs assessment] really daunting. I'm preparing for it like it's an exam! I talk to people and we prepare together. It's about just letting people know what to expect, how to answer questions, and how to avoid them being able to take more away from you. So, for example, if they ask me, "Can you cook?" I will say, "I'm not confident in the kitchen." And if they ask me, "Can you walk to the bus stop?" I will say, "Only when I have my son with me."
Julie continued giving examples of how she intended to avoid yes or no questions in her assessment. Her objective was to introduce complexity and ambiguity in her responses. The reduction of experience in communication with health and welfare assessors that had been so familiar to her in the past (see Smith 2017a, 2017b) has changed in this new assessment. If Julie can walk to the bus stop, she is presumably fit to work. If she cannot cook, they might provide a device that will help her in the kitchen. If she is not confident in the kitchen, providing solutions becomes more difficult. Again, it is a familiar reconstitution of the reduced person (Smith 2017a) and a performance of sorts, this time of limited bodily function.

Julie passed her PIPs assessment on January 13, 2018. She shared with me, discreetly, that she managed to see an increase in her welfare income as a result of the assessment. The significance of preparation for the PIPs assessment cannot be underestimated. Its value, over time, is not scalable; rather, it is multifaceted and proves beneficial to both the enduring social networks of support in the cul-de-sac and to the justification of this form of assessment by government. $^{6}$

For Julie, the process of experiencing the stress and anxiety of needing to prepare, then knowing how to prepare and being successful because of her preparation, is what dependence on welfare looks like in the everyday. The persistent moments of financial threat and crisis have transformed into an enduring sense of familiarity with uncertainty and have produced social strategies of dealing with anxieties around making ends meet in and around this cul-desac. The duration of experiences of poverty and uncertainty is significant in the creative ways in which persistent crises ${ }^{7}$ are dealt with socially (cf. Dalsheim 2015: 8). The diversity of self-management in financial uncertainty is routinely recognized and appreciated in neighborly relations in the cul-de-sac (Smith 2017a). The ongoing welfare reforms, threats of sanctions, and cuts to welfare payments since $2010^{8}$ have introduced many "befores," which are often ref- 
erenced when collective experiences of anxiety about sanctions, cuts, and transferals of benefits payments are discussed between neighbors and family when drawing on (primarily financial) support (cf. Caton 2014: 246). Those "befores" are familiar events they overcame collectively. When these past events are drawn upon and incorporated into present narratives of the future, people on the cul-de-sac imagine more of the same in the future: more moments of financial crisis and drawing on the safety nets they have established among themselves (Smith 2017a, $2017 b$ ), thereby imagining several "afters" as they discuss the significances of the interdependent relationships they cultivate in each other (cf. Caton 2014: 253). Other forms of social relations, including relations of obligation and exchange, explicitly hinge on the shared understanding of what life is like when one is dependent upon state welfare today (Smith 2017b).

\section{Endurance and the future}

Narrations of the "poverty trap," as some blanket it (e.g., Sachs 2006), elicit an image that obscures much more nuanced experiences of what Ghassan Hage refers to as an existential immobility or "stuckedness"-an "inability to articulate a narrative of the future that [they] can believe will be any different from their present and historical circumstances" (2009: 97). In Harpurhey, this form of existential immobility is not dealt with locally through pursuing mobility (i.e., either physically moving or achieving a form of social mobility out of their current predicaments) or even through resistance or protest (cf. Day et al. 1999). Neither social nor physical mobility is felt to be an option for most people in the cul-de-sac, with the exception of Ben. Neither is resistance or protest as the risks these processes import are far too great to participate in while struggling to maintain household finances. This is not political apathy. This form of immobility is not easily addressed through policy. It is not easily framed analytically as resilience in situations of crisis (Rogers
2013). Rather, it appears as a form of endurance as people carry on living through the registers of uncertainty in their lives.

This carrying on and dealing with the changes that welfare reforms introduce (see Smith 2017a) as a form of perpetual existential immobility involves enduring change well, persistently, and indefinitely. The introduction of the PIP assessment is surmountable precisely because expressions and imaginations of the future make explicit what is required of them as they make ends meet and adapt to the systematic withdrawal of state financial support. The collective response to imposed change involves what Stef Jansen has described as a sort of "pattering in place" (2015: 160). In his ethnography of historicized hope in Dayton Meantime in Bosnia and Herzegovina (BiH), Jansen's interlocutors work toward hoping for "normal lives" (see also, Jansen and Kleist 2016). In Harpurhey, we find that their "pattering in place" involves the local perception of recurring periods of "survival time, the time of struggling, drowning, holding onto the ledge, treading water" (Berlant 2011: 169), which will inevitably be repeated, again and again, at some point in the near future. The safety net provided by friends, neighbors, and family hinges on the same welfare system that they all depend upon to stay afloat. "Pattering in place" in Harpurhey can only happen collectively and is dependent upon state support.

The management of uncertainty is mediated by the collective awareness of the repetition involved in struggling to make ends meet. This is similar to Lauren Berlant's shared sense of “crisis-ordinariness" (Berlant 2011: 10), as it takes place in a protracted present, a persistent and familiar prevention of the realization of a "good life" (Jansen 2015: 169), the very prevention of which is acknowledged and mapped onto imaginations of futures in Harpurhey. Berlant discusses the persistence of individual attachments to a neoliberal vision of the good life, including being free from the shackles of dependence upon state welfare in order to "carve out relations of reciprocity that seem fair and that foster life as a project of adding up to something 
and constructing cushions for enjoyment" (2011: 3). Reciprocity, in terms of "giving back" to the state rather than being dependent upon it, and the idea of being in the "right" kind of reciprocal relationship with the state ${ }^{9}$ should, according to this vision, give access to individuals to upward social mobility, job security, and fulfillment in life (Berlant 2011: 3). In Harpurhey, we see the motivations for the performance of a desire for independence from state welfare in sharp relief. They do, indeed, perform these aspirations when dealing with the bureaucratic arms of the state (i.e., in the Job Centre or in Work Clubs, mapping out their lives accordingly) (Cruikshank 1997). But then they go home. Neighbors and family reaffirm, revalue, and maintain strategies to deal with the new forms of uncertainty and threat that they regularly face, which are illustrated when imagining and discussing their future lives together, collectively. Their collective and familiar "pattering in place" (Jansen 2015: 160) becomes a repository for collective memories to reencounter in future moments of uncertainty.

Yet, there is something extraordinary about the particular relationship Julie has with Ben, as his mother. Dependence on welfare with a "dependent" of her own raises particular contingencies and unknowns for Julie. She searches daily for a reencountering with something that can help her make sense of and deal with Ben's potential moment of separation from her, and from Harpurhey. In the face of impending radical change in the household, Julie can imagine more of the same for Ben, and this frightens her.

\section{Julie: Mother, future-maker}

Parenting marks time in the most intimate of ways. It also confronts parents with the passing of time in terms of biological "growth" that sequences time for us (Strathern 2011). For instance, Julie often explains, "Having a child definitely makes you notice time passing [her emphasis]. It also makes you imagine their future life, as adults, 'leaving the nest."' For Julie, this imagination work began the day Ben was born.
At the time when Julie was dealing with the DWP and the PIP assessment, Ben was categorized as a "non-dependent"10 living at home with Julie. His student status protected their household income from housing and council tax benefits reductions. Once Ben completes his university degree in a year's time, and if he remains at home, Julie and Ben face a deficit in the household weekly income. Being classified as a "non-dependent" and no longer in full-time study and still at home, Julie will lose approximately 15 percent of her housing benefit depending on Ben's gross weekly income from his part-time employment. If Ben were to remain at home after completing his degree and remain in employment as a non-dependent, Julie's council tax support will be reduced by anywhere between 14.70 to 76.35 (pounds sterling) per week, depending on Ben's gross income. If Ben were to move out of the home when he finishes his degree, Julie's housing benefit and council tax support will not be changed, but they anticipate that Ben would lose his car and would not be able to continue providing Julie with financial support.

Julie and Ben have negotiated the deficit that Ben will need to "make up" when he loses his student status. This includes rent and council tax contributions as well as contributing to other household finances. Julie explains that the mechanics of maintaining a sufficient income for the household are dependent on what are already fluctuating hours at Ben's place of work. Equally, Ben will need to be able to afford further qualifications for teaching, including achieving two intermediate levels of training for coaching, which cost $£ 1000$ each, and for which there is no bursary. But Julie's concerns are not only about the money he needs and that she cannot provide. Julie explained the ways in which she and Ben have negotiated their next steps over the coming year and addressed why the possibilities of Ben moving out of Harpurhey are limited:

There is a real fear for us, and it's not just about money. And dealing with the bene- 
fits people just opens up chances for them to take more money off us. I would love for Ben to be able to leave the nest and find a place of his own. But he's not a priority for a council house. I've told him to put his name on the list, but it could take years, maybe never. He has looked into private renting, but he needs a guarantor, and I can't be that for him because I'm on benefits. We don't have the money for a deposit anyway. He doesn't have family who can help him. It does look like Ben will be staying at home after he finishes his degree. And his future will be that people will see where he lives and where he comes from and they'll see him as a risk, as scum, even though he has worked so hard to be able to make a life of his own. I worry that he'll never escape Harpurhey. I always imagined Ben being able to say, "Whatever criticisms you have, you can't have them about me." I still hope for that, but I can't see how it's going to happen. I only see how it won't.

Julie imagines a future to be there for Ben but cannot articulate her vision or its landscape. She has aspirations for Ben, but there is no new object upon which this aspirational future can rest. Her imagination is trapped, or stuck, within the present world of which it is a product. Neighbors and family, who have been actively linked in reciprocal obligations and established networks of support (cf. Stack 1974) over time to Ben's upbringing, offer little help in Julie's imagination work of Ben's future beyond Harpurhey. She has no prior knowledge or social networks to reencounter. Her family cannot help him move out of Harpurhey. There are no available bursaries for what Ben needs to do to progress in his career after university. Neighbors and family have little advice they can give.

Yet, Julie and Ben remain committed to looking for ways to pursue a future for Ben in which he is "unstuck," emancipated from the existential immobility of the generations before him. They approach a rupture in everything they have had before. The cruelty of the uncertainties involved require Julie to oscillate between two temporalities of engagement with the future, which are made incompatible through the scrutiny and requirements of the state: on the one hand, thinking about and helping to prepare for Ben's future "good life," away from Harpurhey, despite not knowing how to achieve it, and, on the other hand, dealing with the immediate requirements of the state to refocus aspirational thinking to the everyday "pattering in place" that Julie's and Ben's situations require to get by in the everyday. Julie outlines the importance, as a mother and future-maker, of preparing the groundwork for Ben's future. She recalls her ability, over time, to take future-oriented actions for Ben's future escape from Harpurhey. Similar to, but not the same as Rebecca Bryant and Daniel Knight's recent work on "orientations to the future" (2019), of hope, anticipation, speculation, expectation, faith, and fate, Julie does actively claim the future in numerous affective ways often evidenced in her recalling the past and narrating hope for Ben's future. However, and significantly, Julie also is pointing directly to a disconnect between action and imagination: between engaging with these kinds of orientations in the present and the persistent inability to take action on that which she cannot imagine or grasp. What can Julie expect or anticipate for Ben?

In their conceptualizations of "ruptures" as forceful forms of discontinuity in everyday life, Martin Holbraad, Bruce Kapferer, and Julia Sauma (2019) have argued that ruptures have a dual aspect in that they represent a "critical cutor 'switch point' that instigates a significant break with existing conditions, but by the same token, ruptures can act as a positive or dynamic impulse towards escape, redirection, reconstitution and sometimes renewal" (2019: 1). Value emerges through a break or multiple breaks with something. They address ruptures as actions, as ongoing, rather than as historical events. They are spatio-temporally transformative and productive, regenerative, and therefore neither entirely positive nor entirely negative. But they 
provide the condition for possibilities dynamically, across time, space, and perspectives.

State interference in Ben's future movements and decisions, and in Julie's financial future, does not push against them with opposing force. It appears to be a motivating force to get Ben to move away from Harpurhey-the best option, and a potential rupture, for Julie and Ben, nonetheless. However, Julie is scrambling to locate the condition of possibilities for Ben. As Julie attempts to imagine a future for Ben, state interference cuts through them, refusing their logic, their modes of operation, their intimate interdependence. They are situated, stuck, enduring. Julie's future-making is ruptured.

The relationship between Julie and Ben, as mother and child, presents ruptures within this oscillation. Ruptures within ruptures: the inarticulacy of imagination, "existential ruptures" (Pedersen 2019) of the individual immobilized through dependence on state welfare, internalized ruptures as part of motherhood as hope is formed and then dashed. These ruptures multiply and ultimately oppose political and social expectations.

The familiarity of dealing with state requirements and radical changes to welfare provision offers little insight into how to approach this impending moment of separation for Julie and Ben. Instead, they are repeatedly pulled back to present, immediate concerns; concerns that reproduce the stuckedness of which Julie is so familiar. Julie's imagination work for Ben's future is not a complete break with the past, however. Neither is it an historical event to reencounter. Julie has pointed precisely to this inability to render Ben's future in narrative form as the very mark of multiple personal and political ruptures at once (cf. Greenhouse 2019).

Over marked time and being confronted with its passage, Julie has worked at imaging a better future for her son. She has managed the recurring destabilization of welfare reforms, managed crises well and with endurance, and remained committed to the possibility of a "good life" for Ben, despite her dependence on a state that reproduces the very dominant prog- ress narrative that Julie has been unable to access herself. However, now, as Ben approaches the end of his degree, Julie finds herself "only [able] to see how it won't" happen. She went on to explain:

I worry. Because he's starting off adult life with debt and he'll have to pay it off. And I wish I could do more. As a parent I wish I could help him more financially but it's not possible. And I think about what a good lad he is. When he was in primary school he was always well behaved and polite. That's the kind of lad he is. So I try to look at how he's grown up and that he's young and fit and getting qualified. Luckily Ben has his job at [the shop] and that keeps his car on the road. And he will need that car to get a better job. But I also look at the barriers he's facing and that maybe he doesn't have enough experience and that I can't help him with money. He doesn't have enough money to get qualified right now. I definitely think about the challenges more than the positive things he has going for him because of the lack of jobs, his age, his lack of experience, that he faces stereotypes because of where he comes from. I think he gets worried but he doesn't talk about it too much. I just hope he gets the job he really wants to do. And I know he can do it. If anyone can, he can.

As his mother, she narrates the past, and present, "making history", "making events" (Rosaldo 1993: 128-129) as she attempts to make sense of what to do next. Considering the multiple directions that ruptures in imagination have taken for Julie (cf. Holbraad et al. 2019), Ben's future appears as one that is peppered with the same social barriers that Julie and Ben have faced over time but overcame together. She has a sense of temporal elasticity; she can imagine time potentially going back and forth on itself, but not on relationships, not with Ben (cf. Strathern 2011). 


\section{Conclusion}

For Julie and Ben, both events-one unexpected, one expected-demonstrate the interdependence whereby everything that Julie has done and continues to do in her "stuckedness," in her pattering in place in the cul-de-sac, including going through the preparations for and sitting the PIP assessment, provides a foundation and consistent household from which Ben can escape the risk of becoming stuck. On the other hand, from Julie's perspective, what cuts through this existential immobility are multiple existential ruptures that form part of her experience of the conditions of poverty that are reproduced in a post-welfare moment.

An unexpected welfare reform, which is perceived locally to pose a threat to the futures of households around the cul-de-sac, can be overcome by the mobilization of networks of support, the production of knowledge about what it takes to pass the assessment, and the rehearsing of responses as preparation-a collective corrective in ruptures of imagination. Julie's successful assessment outcome demonstrates the significance of the interdependent relationships that neighbors and families have cultivated and have come to rely upon for survival, value, and enjoyment. Yet, the existential immobility that these networks foster appears inimical to the neoliberal vision of the good life that includes financial self-sufficiency as a primary mode of independence. In order to "carve out relations of reciprocity that seem fair and that foster life as a project of adding up to something and constructing cushions for enjoyment" (Berlant 2011: 3), the idea of being in the "right" kind of reciprocal relationship with the state should, according to this vision, give access to individuals, including Ben, to a future of upward social mobility, job security, and fulfillment in life.

One may argue that Julie and Ben are situated in what Bryant has incisively identified as "the uncanny present," a viscerally felt "present" that brings "present-ness to the fore" and makes it unfamiliar. Futures cannot be anticipated in the uncanny present, and it is uncanny because of the "severing or questioning of the links between past, present and future that ordinarily allow us to anticipate" (2016: 21, original emphasis). However, the relationship between parent and child is, arguably, of a particular order (Strathern 2011), for which moments of rupture produce new kinds of contingencies. The disconnect between action and imagination in Julie's protracted present of uncertainty leaves her stuck in an over-familiarized present. However, parenthood punctuates and marks time for us. For Julie and Ben, as mother and (biological) child, their relationship has both atemporal and temporal dimensions (Strathern 2011). It signifies a retrospective state for Julie that is fixed in relation to an immutable direction of growth. Ben will have a future. What it will look like is unimaginable at present. Yet, Julie maintains glimmers of hope for Ben's future. "I know he can do it. If anyone can, he can." Julie finds hope in her adeptness at oscillating between the different temporal dimensions that parenting introduces. What can take root in moments in which imagined futures are interrupted by the very structures and requirements that create dependence on the state in the first place? For Julie, as mother and future-maker, it remains a mother's hope.

Katherine Smith is a lecturer in Social Anthropology and Director of the BA in Social Sciences Programme at the University of Manchester, UK. Her research interests include lived experiences of poverty, welfare dependence, social class, belonging, political representation, and (un)fairness and (in)equalities in Britain. She is author of Fairness, Class and Belonging in Contemporary England (Palgrave Macmillan) and co-editor of Extraordinary Encounters: Authenticity and the Interview (Berghahn Books).

Email: Katherine.smith-3@manchester.ac.uk 


\section{Notes}

1. General Certificate of Secondary Education (GCSE) is part of the national curriculum in England and Wales. They include general subjects, including English, Maths, Science, taught to pupils aged 14 to 16 , in years 10 and 11. GCSEs are examined. The results have a significant bearing on whether or not a child can progress on to A-Levels. Advanced Levels (A-Levels) are qualifications offered by schools and colleges for students aged between 16 to 19 that focus on academic subjects that are indicative of what the pupil will then go on to study at university.

2. Harpurhey has been identified as the "most deprived area in England" by multiple research and governmental organizations, including in the government-sponsored report from Oxford University on Indices of Deprivation, webarchive.nationalarchives.gov.uk/+/http://www .communities.neighbourhoodrenewal/deprivation/deprivation07 (accessed December 17, 2017), and by Manchester City Council, http:// www.manchester.gov.uk/.../id/.../f1_indices_ of_deprivation_2015_-_manchester.pdf (accessed December 17, 2017).

3. These are independent assessors employed by private corporations, including Atos Healthcare or Capita, who are contracted by and work on behalf of the Department of Work and Pensions (DWP).

4. Claimants have the right to an appeals process. The appeals process can take several weeks to complete and does not guarantee reassessment or access to PIPs.

5. According to government estimates, the "rolling out" of the transferal from DLA to PIPs was completed in October 2020.

6. Please see https://publications.parliament.uk/ $\mathrm{pa} / \mathrm{cm} 201719 / \mathrm{cmselect} / \mathrm{cmworpen} / 986 / 98602$ .htm for the Eighth Special Report from the Work and Pensions Committee outlining the "key priorities" for the Department in "Improving" PIP assessment procedures, which includes "guidance changes to Case Managers, who decide claims to PIPs" (accessed August 13, 2019).

7. I am using the terms "crisis" and "crises" hermeneutically, to echo the expressions of my interlocutors in the cul-de-sac.
8. In 2010, then-Work and Pensions Secretary Iain Duncan Smith proposed a series of welfare reforms that, despite controversy within his own Conservative government, would be taken up and implemented as part of the Coalition and Conservative government's "austerity" package.

9. Keir Martin 2018, personal communication.

10. The UK Department for Work and Pensions (DWP) defines someone who is 18 years old or older and who normally lives with the Housing Benefit or Council Tax Support claimant-such as an adult son, daughter, relative, or friend-a "non-dependent."

\section{References}

Berlant, Lauren. 2011. Cruel optimism. Durham, NC: Duke University Press.

Bryant, Rebecca. 2016. "On critical times: Return, repetition, and the uncanny present." History and Anthropology 27(1): 19-31. https://doi.org/10 .1080/02757206.2015.1114481.

Bryant, Rebecca, and Daniel Knight, eds. 2019. "Orientations to the future." American Ethnologist, March 8. http://americanethnologist.org/ features/collections/orientations-to-the-future/ orientations-to-the-future-an-introduction.

Caton, Steven, C. 2014. "Henri Bergson in highland Yemen." In The ground between: Anthropologists engage philosophy, eds. Veena. Das, Michael Jackson, Arthur Kleinman, and Bhrigupati Singh, 234-253. Durham, NC: Duke University Press.

Cruikshank, Barbara. 1997. The will to empower: Democratic citizens and other subjects. Ithaca: Cornell University Press.

Dalsheim, Joyce. 2015. “There will always be a Gaza war: Duration, abduction and intractable conflict," Anthropology Today 31(1): 8-11. https:// doi.org/10.1111/1467-8322.12152.

Day, Sophie, Evthymios Papraziarchis and Michael. Stewart, eds. 1999. Lilies of the field: Marginal people who Live for the moment. Boulder, CO: Westview Press.

de Pina-Cabral, João. 2018. "Filiation as a crossroads in Bahia." Anthropology Today 34 (2): 5-8. https://doi.org/10.1111/1467-8322.12418.

Greenhouse, Carol, J. 2019. "Times life the present: Political rupture and the heat of the moment." In Ruptures: Anthropologies of discontinuity in 
times of turmoil, eds. Martin. Holbraad, Bruce. Kapferer, and Julia F. Sauma, 70-92. London: UCL Press.

Hage, Ghassan. 2009. "Waiting out the crisis: On stuckedness and governmentality." In Waiting, ed. Ghassan. Hage, 97-106. Melbourne: Melbourne University Press.

Holbraad, Martin, Bruce Kapferer, and Julia F. Sauma, eds. 2019. Ruptures: Anthropologies of discontinuity in times of turmoil. London: UCL Press.

Jansen, Stef. 2015. Yearnings in the meantime: "Normal lives" and the state in a Sarajevo apartment complex. Oxford: Berghahn.

Jansen, Stef, and Nauja Kleist, eds. 2016. "Introduction: Hope over time: Crisis, immobility and future-making." History and Anthropology 27(4): 373-392.

Koch, Insa. 2015. "The state has replaced the man." Focaal: Journal of Global and Historical Anthropology 73: 84-96. https://doi.org/10.3167/ fcl.2015.730107.

Pedersen, Morten, Axel. 2019. "Inner revolution: Reaction and rupture in a Danish Lutheran movement." In Ruptures: Anthropologies of discontinuity in times of turmoil, eds. Martin.
Holbraad, Bruce. Kapferer, and Julia F. Sauma, 93-115. London: UCL Press.

Rogers, Peter. 2013. "Rethinking resilience: Articulating community and the UK riots." Politics 33(4): 322-333. https://doi.org/10.1111/14679256.12033.

Rosaldo, Renato. (1989) 1993. Culture and truth: The remaking of social analysis. Boston: Beacon Press.

Sachs, Jeffrey. 2006. The end of poverty: Economic possibilities for our time. New York: Penguin Books.

Smith, Katherine. 2017a. "'You don't own money, you're just the one who's holding it': Borrowing, lending and the fair person in North Manchester." Sociological Review Monographs 65(1): 121136. https://doi.org/10.1177/0081176917693528.

Smith, Katherine. 2017b. "Don't call the cops on me, I won't call them on you': Self-policing as ethical development"' In Realising the city: Urban ethnographies of Manchester, eds. C. Lewis and J. Symons, 189-204. Manchester University Press.

Stack, Carol. 1974. All our kin: Strategies for survival in a black community. New York: Harper and Row.

Strathern, Marilyn. 2011. "What is a parent?" Hau 1(1). https://doi.org/10.14318/hau1.1.011. 